\title{
Vastuullisuus elintarvikeketjussa
}

Sari Forsman-Hugg ${ }^{1)}$, Juha-Matti Katajajuuri ${ }^{2)}$ Johanna Mäkelä ${ }^{3)}$ Jaana Paananen $^{1)}$ Inkeri Pesonen $^{2)}$ ja Päivi Timonen ${ }^{3)}$

${ }^{1)}$ Maa- ja elintarviketalouden tutkimuskeskus, Taloustutkimus, Luutnantintie 13,00410 Helsinki, sari.forsman-hugg@mtt.fi,jaana.paananen@mtt.fi

${ }^{2)}$ Maa- ja elintarviketalouden tutkimuskeskus, Biotekniikka- ja elintarviketutkimus, 31600 Jokioinen, juha-matti.katajajuuri@mtt.fi, inkeri.pesonen@mtt.fi

${ }^{3)}$ Kuluttajatutkimuskeskus, PL 5, 00531 Helsinki, johanna.makela@ncrc.fi, paivi.timonen@ncrc.fi

Yhteiskuntavastuu on viime vuosina noussut liiketoiminnan keskiöön myös suomalaisessa keskustelussa. Yhteiskuntavastuu (vastuullisuus, yritysvastuu) tuo uudenlaisia ulottuvuuksia ja haasteita myös elintarvikealan yritysten johtamiseen; yritysten tulee muun muassa osoittaa toimintansa vastuullisuus käytännön todennettavina tekoina ja avoimuuden lisäämisenä. Ketjunäkökulma tekee vastuullisuudesta entistä moniulotteisemman. Kun elintarvikeketjuun monesti sisältyy useita raaka-aineketjuja ja yritykset toimivat globaaleilla markkinoilla, ketjun ja informaation hallinta niin ympäristön, sosiaalisten kuin taloudellistenkin kysymysten kannalta on entistä haasteellisempaa. Ruoan tuottaminen vastuullisesti edellyttää, että koko elintarvikeketju huolehtii toimintansa vaikutuksista ympäröivään yhteiskuntaan.

Vastuullisuuden sisällön rakentamiseksi Maa- ja elintarviketalouden tutkimuskeskus (MTT) ja Kuluttajatutkimuskeskus selvittävät yhteistyössä elintarvikealan yritysten ja sidosryhmien kanssa, mitä vastuullisuus elintarvikeketjussa tarkoittaa ja miten sitä voisi mitata. Hankkeessa arvioidaan ja kehitetään vastuullisuutta ja vastuullisuuden tuotteistamista suomalaisessa elintarvikeketjussa ja osallistutaan vastuullisuuden jaetun käsityksen rakentamiseen. Vastuullisuutta lähestytään Triple Bottom Line (TBL) -kolmijaon mukaan taloudellisen vastuun, sosiaalisen vastuun ja ympäristövastuun näkökulmista. Artikkelin tavoitteena on yhtäältä kuvata vastuullisuuden sisällön rakentamista iteratiivisena prosessina ja sidosryhmädialogina ja toisaalta muodostaa käsitys vastuullisuuden sisällöstä kolmen esimerkkituotteen - ruisleipä, margariini ja broilerituotteet - ja niiden tuotantoketjujen osalta.

Vastuullisuuden sisältöä rakennetaan hankkeessa yhteistyössä ja vuorovaikutuksessa tutkijoiden, mukana olevien yritysten ja niiden sidosryhmien - mukaan lukien kuluttajat - sekä eri alojen asiantuntijoiden kanssa. Hanke yhdistää useita lähestymistapoja ja menetelmiä, muun muassa monipuolista aineistonkeruuta, toimintatutkimusta, konstruktiivista teknologian arviointia (CTA) ja työpajatyöskentelyä. Hankkeen ensimmäisessä vaiheessa kerättiin ketjukohtaista aineistoa esimerkkituotteiden tuotantoketjusta erityisesti vastuullisuuden näkökulmasta. Tämän pohjalta laadittiin taustaaineistot sidosryhmätyöpajoja varten. Artikkelissa esitetään sidosryhmädialogin tuotoksia perustuen kolmeen tapauskohtaiseen työpajaan, joissa tuotettiin vastuullisuuteen liittyviä ideoita, jäsenneltiin ideoita TBL-ulottuuvuuksien alle ja arvotettiin niitä.

Sidosryhmädialogin perusteella ympäristöasiat ovat vastuullisuuden kannalta keskeisessä roolissa. Huoli ympäristöstä on yhteinen ja jaettu kaikkien esimerkkiketjujen osalta. Vastuullisuuteen liitettiin vahvasti myös oikeudenmukainen tulonjako ketjussa, terveellisyys, puhtaus ja tuoteturvallisuus, kuluttajan vastuu sekä broileriketjun kohdalla eläinten hyvinvointi. Sidosryhmädialogissa oli jonkin verran tapauskohtaisia eroja. Elinkaarilähtöinen ajattelutapa vastuullisuuden arviointiin sai kannatusta sidosryhmäkeskusteluissa. Ketjulähtöinen vastuullisuuden tarkastelu edellyttäisi elinkaariajattelun laajentamista myös sosiaalisen vastuun kysymyksiin.

Hanke vahvistaa sidosryhmädialogin tarvetta vastuullisuuden sisällön rakentamisessa, vaikka konsensuksen saavuttaminen vastuullisuuden jaetun käsityksen rakentamiseksi onkin haasteellinen ja pitkä prosessi. Tulokset auttavat elintarvikealalla toimivia yrityksiä hahmottamaan, millä vastuullisuuden osa-alueella olisi eniten merkitystä kuluttajille ja muille sidosryhmille. Hanke tarjoaa myös aineksia vastuullisuudesta käytävään yhteiskunnalliseen ja poliittiseen keskusteluun.

Asiasanat: Yhteiskuntavastuu, vastuullisuus, ruoka, elintarvikeketju, kuluttajat, sidosryhmädialogi, vuorovaikutus 


\section{Johdanto}

Yhteiskuntavastuu (Corporate Social Responsibility, CSR) on viime vuosina noussut liiketoiminnan keskiöön myös suomalaisessa keskustelussa. Vastuullisuus tuo uudenlaisia ulottuvuuksia ja haasteita myös elintarvikealan yritysten johtamiseen. Ylevät arvot ja periaatteet eivät enää riitä, vaan yritysten tulee osoittaa ja todentaa vastuullisuus käytännön tekoina ja avoimuuden lisäämisenä. Yksi tapa vastuullisuuden sisällön rakentamiseen on sidosryhmädialogi (Wilenius 2005).

Vastuullinen toimintatapa on mahdollista ankkuroida yritykseen vain, jos vastuullisuudelle käsitteenä pystytään rakentamaan merkityksellinen ja yhteinen sisältö (Cramer ym. 2004, Wilenius 2005). Vakiintunut lähestymistapa vastuullisuuteen perustuu niin kutsuttuun kolmoistilinpäätöksen (Triple Bottom Line, TBL) ulottuvuuksiin: taloudellinen ja sosiaalinen vastuu sekä ympäristövastuu (Elkington 1997). Vastuullisuudessa on kyse laajemmasta näkökulmasta kuin, että yritykset toimivat pelkästään lainsäädännön puitteissa tuottaen peruslaadun kriteerit täyttävää ja turvallista ruokaa. Yhteismitallisen elintarviketalouden vastuullisuuden sisällön rakentaminen on haasteellista, sillä vastuullisuus ei ole absoluuttinen käsite vaan siihen liittyvät tavoitteet ja näkökulmat kehittyvät ja muuttuvat ajan myötä. Elintarvikeketjun laatu- ja vastuukäsityksiä selvittäneen tutkimuksen (Forsman-Hugg ym. 2006) mukaan ketjun toimijoilla ei vielä ole yhteistä käsitystä siitä, mitä vastuullisuus elintarviketaloudessa tarkoittaa. Vastuukysymykset elintarvikeketjussa ovat moniulotteisia, ja niihin sisältyy usein arvoristiriitoja erityisesti taloudellisen vastuun ja muiden vastuullisuuden osa-alueiden välillä.

Ketjunäkökulma tekee vastuullisuudesta entistä moniulotteisemman. Kun elintarvikeketjuun monesti sisältyy useita raaka-aineketjuja ja yritykset toimivat globaaleilla markkinoilla, ketjun ja informaation hallinta niin ympäristön, sosiaalisten kuin taloudellistenkin kysymysten kannalta on entistä vaikeampaa. Ruoan tuottaminen vastuullisesti edellyttää, että koko elintarvikeketju huolehtii toimintansa vaikutuksista ympäröivään yhteiskuntaan. Vastuullisuudessa on kyse myös ei-toivottujen vaikutusten hallinnasta. Ketjunäkökulman huomioon ottaminen elintarvikeketjun vastuullisuuskeskustelussa on kuitenkin perusteltua, sillä elintarvikkeiden valmistaminen kattaa useita vaiheita ja prosesseja tuotantopanosten ja raaka-aineiden tuotannosta lopputuotteeseen asti. Vaikutukset ovat usein suuremmat muualla kuin siellä, missä ketjua koskevat strategiset päätökset tehdään. Tutkimukset (esim. Katajajuuri ym. 2005) ovat osoittaneet, että merkittävä osa elintarvikkeiden tuotantoketjun ympäristövaikutuksista aiheutuu alkutuotannosta eikä varsinaisen lopputuotteen valmistuksesta.

Vastuullisuuden määrittelyn lisäksi keskeinen kysymys on, kuinka mitata vastuullisuutta. Tosin kiistatonta ei ole sekään, voiko vastuullisuutta ylipäätään (Korhonen 2003a). Kuitenkin vain mittaamalla vastuullisuutta yritykset voivat kehittää ja johtaa vastuullista toimintaansa. Vastuullisuus liiketoiminnan strategiakeskustelussa on keskittynyt tähän asti pitkälti kestävyyden ympäristöulottuvuuteen (Korhonen 2003b). Niin ikään vastuullisuuden mittaamisen juuret ovat ympäristötilinpidossa ja -raportoinnissa. Haasteena on kehittää vastuullisuuden sekä määrällisiä että laadullisia mittareita ottaen samanaikaisesti huomioon vastuullisuuden kaikki osa-alueet. Vastuullisuuden mittaamisen tutkimus on vasta nuorta, etenkään sektorikohtaisia ja vertailevia toimialarajat ylittäviä tutkimuksia ei juuri ole (Salzmann ym. 2006) puhumattakaan tarjontaketjunäkökulman huomioon ottamisesta (Veleva \& Ellenbecker 2000). Mittareiden kehittäminen elintarvikeketjun näkökulmasta edellyttää ensin vastuullisuuden yhteisen sisällön tunnistamisen ja määrittämisen.

Vastuullisuuden sisällön rakentamiseksi Maa- ja elintarviketalouden tutkimuskeskus (MTT) ja Kuluttajatutkimuskeskus selvittävät yhteistyössä elintarvikeketjun yritysten ja sidosryhmien kanssa, mitä vastuullisuus elintarvikeketjussa tarkoittaa ja miten sitä voisi mitata. Kolmivuotisen hankkeen tavoitteena on arvioida ja kehittää vastuullisuutta ja vastuullisuuden tuotteistamista suomalaisessa elintarvikeketjussa ja osallistua vastuullisuuden jaetun käsityksen rakentamiseen. Tämän artikkelin tavoitteena on yhtäältä kuvata vastuullisuuden sisällön rakentamista iteratiivisena prosessina ja sidosryhmädialogina ja toisaalta pohtia vastuullisuuden sisältöä kolmen esimerkkituotteen ja niiden tuotantoketjujen osalta. Hankkeessa on mukana viisi elintarvikeketjun yritystä: Fazer Leipomot, HK Ruokatalo, Kesko, Ravintoraisio ja Suomen Rehu. Hanketta rahoittavat maa- ja metsätalousministeriö, ympäristöministeriön hallinnoima ympäristöklusterin tutkimusohjelma, edellä mainitut yritykset ja tutkimuslaitokset. 


\section{Aineisto ja menetelmät}

Vastuullisuuden sisältöä rakennetaan hankkeessa yhteistyössä ja vuorovaikutuksessa tutkijoiden, mukana olevien yritysten ja niiden sidosryhmien - mukaan lukien kuluttajat - sekä eri alojen asiantuntijoiden kanssa. Tutkijoiden roolina on kerätä ja analysoida olemassa olevaa aineistoa ja tuoda prosessiin oman alan asiantuntemusta ajankohtaisista vastuullisuuden kannalta keskeisistä kysymyksistä ja niiden arvioinnin lähtökohdista ja menetelmistä, esimerkiksi ympäristövaikutusten elinkaariarviointi (LCA, Life Cycle Assessment) ja käyttäjälähtöisyys innovaatioissa. Ketjun toimijat tuovat näkemykset olemassa olevista käytännöistä ja toimintatavoista. Asiantuntijat tuovat näkemyksiään muun muassa oman alansa ajankohtaisista politiikkatoimista ja kehittämislinjauksista.

Vastuullisuuden sisältöä ja kriteerejä rakennetaan iteratiivisena prosessina (Kuva 1). Tutkimushankkeessa yhdistyy useita lähestymistapoja ja menetelmiä, muun muassa monipuolista aineistonkeruuta, toimintatutkimusta, konstruktiivista teknologian arviointia (constructive technology assessment, CTA) ja työpajatyöskentelyä. Vastuullisuuden teoreettisena viitekehikkona on TBL-kolmijako, mutta vastuullisuuden sisällön rakentaminen tehdään pitkälti aineistolähtöisesti perustuen grounded theory -lähestymistapaan (Glaser \& Strauss 1967).

Hankkeen esimerkkituotteet ovat: Fazer Leipomoiden Reilu-ruisleipä, HK Ruokatalon Kariniemen broilerituotteet sekä Keskon markkinoima ja Raision valmistama Pirkka-margariini. Pirkkamargariinista mukana on kaksi tuotetta: Pirkka Margariini 60, jonka Raisio valmistaa Suomessa, ja Pirkka Margariini 25, joka valmistetaan Raision Puolan tehtaalla. Koska tuotteet ja niiden tuotantoketjut ovat erityyppisiä, niiden oletetaan jäsentävän vastuukysymyksiä hieman eri tavoin.

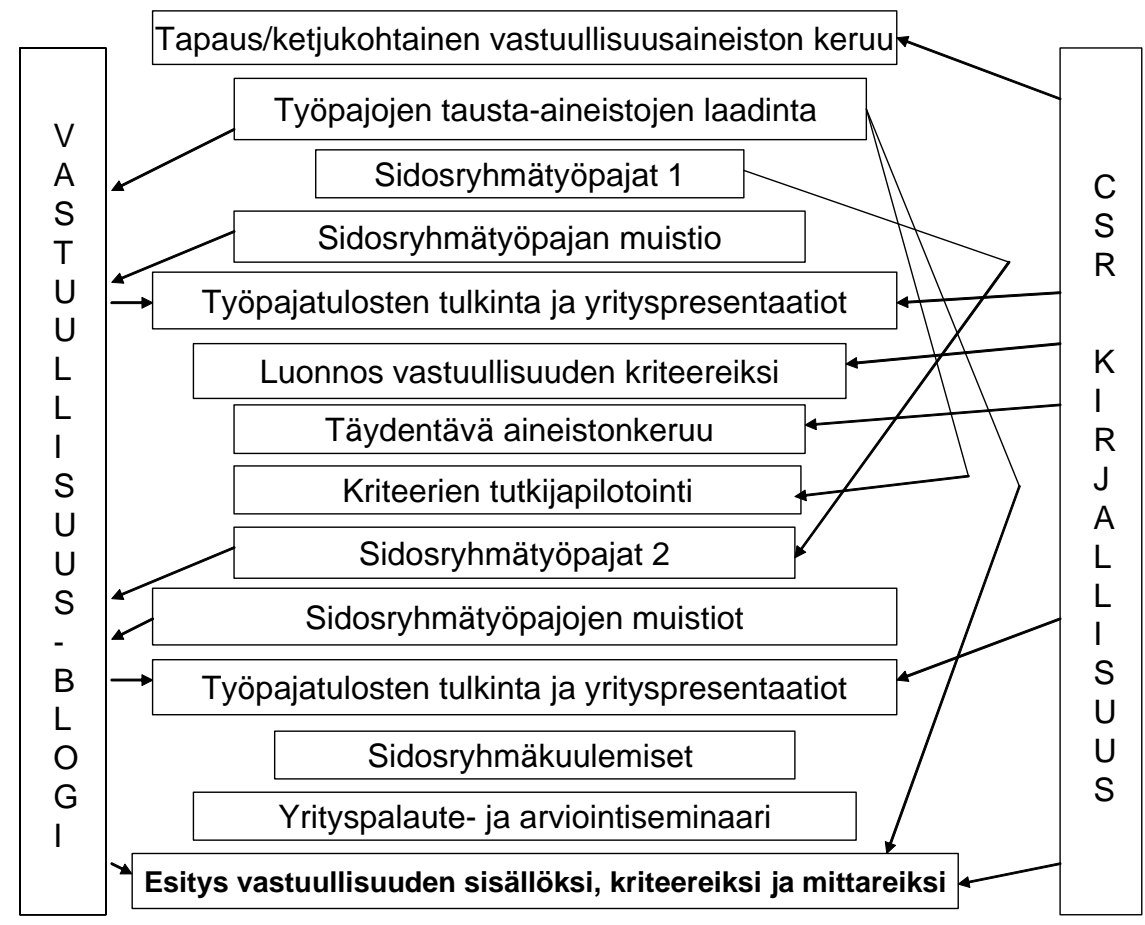

Kuva 1. Tutkimushankkeen eteneminen prosessina.

\section{Ketjukohtaiset vastuullisuus-aineistot}

Hankkeen ensimmäisessä vaiheessa kerättiin ketjukohtaista aineistoa esimerkkituotteiden tuotantoketjusta. Tavoitteena oli kuvata tuotantoketju ja siihen liittyvät vaiheet ja nykyiset toimintatavat mahdollisimman tarkasti sekä erityisesti, miten ketju toimii vastuullisuuden näkökulmasta ja mitkä asiat ovat relevantteja ketjussa vastuullisuuden näkökulmasta. Tietoja kerättiin useista eri lähteistä, muun muassa haastattelemalla yritysten avainhenkilöitä ja ketjun keskeisiä toimijoita, haastattelemalla ja konsultoi- 
malla eri alojen asiantuntijoita ja sidosryhmien edustajia, hyödyntämällä yritysten sisäisiä dokumentteja, yhteiskuntavastuuraportteja, toimialaraportteja, tilastoja ja alaan liittyvää tutkimusta. Yhteistyö yritysten kanssa on ollut tiivistä ja avointa; yritysten edustajien kanssa on kokoonnuttu useita kertoja suunnittelemaan ja keskustelemaan hankkeen vaiheista.

Tutkimuskehikko aineistojen keräämisessä eri case-tuotteille ja -ketjuille oli lähtökohdiltaan sama, mutta siinä oli joitakin tapauskohtaisia eroja. Esimerkiksi eläinten terveyden ja hyvinvoinnin kysymykset olivat näkyvästi esillä broilerituotteiden osalta. Osaa kerätystä aineistosta pystyttiin hyödyntämään suoraan ketjun ja vastuullisuuden kuvaamisessa, osaa hyödynnettiin lähtötietoina esimerkiksi ketjun kokonaisympäristökuormitusten ja työllistävyyden arvioinnissa. Mahdollisuuksien mukaan hankittiin vertailevaa tietoa eri alkuperämaista lähtöisin olevien raaka-aineiden vastuullisuusasioista. Vertailevaa tietoa kerättiin eniten margariinin tapauksessa, koska toinen margariineista on valmistettu Suomessa ja toinen Puolassa. Ketjukohtaisten kuvausten ja vastuullisuustietojen pohjalta kirjoitettiin esimerkkituotteittain ketjuraportit. Ketjuraporteissa vastuullisuuteen liittyvät tiedot luokiteltiin TBL-ulottuvuuksien alle. Seuraavassa on lueteltu, minkä tyyppistä tietoa ketjuraportit sisälsivät:

- Taloudellinen vastuu: maataloustuotannon kannattavuus ja maataloustukien osuus; toimialan kannattavuus, kustannusrakenne, jalostusarvo ja investoinnit; hintamarginaalit, tuottaja- ja kuluttajahinnat; brändin historia ja strategia, kuluttajasegmentit

- Sosiaalinen vastuu; ihmisten työhyvinvointi tuotantoketjussa, palkkaus, työturvallisuus, koulutus; ketjun työllisyysvaikutukset; tuoteturvallisuuden hallinnan periaatteet ja omavalvonta; tutkimus ja tuotekehitys; asiakaspalautteet; eläinten terveyden ja hyvinvoinnin periaatteet ja toteutuminen tuotantoketjussa

- Ympäristövastuu: ympäristöhallintajärjestelmän kuvaus, keskeisten ympäristöongelmien ja riskien kuvaus, tiedot ympäristöauditoinneista, ketjun ja yritysten materiaali- ja ympäristötaseet, tutkimustulokset tuotteen ja/tai sen pääraaka-aineiden elinkaariarvioinneista tai vastaavista selvityksistä

Hankkeen aikana kerätyt aineistot ja tiedot on dokumentoitu prosessin läpinäkyvyyden ja luotettavuuden varmistamiseksi. Haastattelut on nauhoitettu ja litteroitu, ja tapaamiset yritysten edustajien kanssa on dokumentoitu muistioina ja tutkijoiden kenttäpäiväkirjoina.

Ketjuraporttien pohjalta laadittiin yleistajuiseen ja vihkon muotoon kirjoitetut 30-40 -sivuiset työpaja-aineistot, joissa kuvattiin esimerkkituotteiden tuotantoketjut ja niiden toimintaan liittyviä vastuullisuuden ulottuvuuksia. Työpaja-aineistojen tehtävänä oli toimia virikkeenä sidosryhmätyöpajoille.

\section{Sidosryhmätyöpajat}

Hankkeen sidosryhmädialogin keskiössä ovat vuorovaikutteiset ja osallistavat työpajat. Vastaavantyyppisiä sidosryhmätyöpajoja on sovellettu konstruktiivinen teknologian arvioinnissa (esim. Heiskanen 2005). Työpajojen kantavana ajatuksena on, että erilaisten ja eri tahoja edustavien ihmisten ja asiantuntijoiden kohtaamisessa syntyy oivalluksia, joita voidaan hyödyntää vastuullisuuden jäsentämisessä, määrittelyssä ja arvioinnissa. Jokaisen esimerkkituotteen osalta järjestettiin vuonna 2007 työpaja, jossa vastuullisuutta lähestyttiin tuotantoketjun näkökulmasta. Työpajoihin rekrytoitiin osallistujia seuraavista ryhmistä: 1) tuotantoketjun toimijat, 2) kuluttajia Kuluttajatutkimuskeskuksen Kuluttajapaneelista sekä 3) tutkimuksen, etujärjestöjen, kansalaisjärjestöjen ja muiden sidosryhmien edustajat. Rekrytointi tehtiin siten, että kustakin pääryhmästä oli samankokoinen edustus. Toisella työpajakierroksella keväällä 2008 keskitytään kuluttajien näkökulmaan, ja osallistujiksi rekrytoidaan vain kuluttajia.

Jokaiseen työpajaan osallistui noin 30 osallistujaa, ja ne järjestettiin iltaisin kolmetuntisina tilaisuuksina. Osallistujat saivat pari viikkoa ennen työpajaa tutustuttavaksi työpajan tausta-aineiston, joka sisälsi tietoa tiivistetysti ja kansankielellä kirjoitettuna tuotantoketjun taloudellisista ja sosiaalisista kysymyksistä ja tekijöistä sekä ympäristövaikutuksista. Työpajassa osallistujat jaettiin kolmeen ryhmään ennalta määriteltyihin tapauskohtaisiin teemoihin. Esimerkiksi ruisleipä-työpajassa teemat olivat: 1) ruisleivän raaka-aineet, 2) ihmiset tuotantoketjussa ja 3) ruisleivän arvoketjun vastuullisuus. Työpajan kulku ja aikataulu oli tarkkaan käsikirjoitettu. Kullakin pienryhmällä oli vetäjä, jonka tehtävänä oli moderoida keskustelua mutta ei ottaa kantaa keskusteluun. Pienryhmäkeskustelut koostuivat 
kolmesta vaiheesta. Ensin osallistujat tuottivat vapaasti paperilapuille ideoita niistä asioista, jotka heidän mielestään olivat vastuullisuuden näkökulmasta keskeisiä ja tärkeitä pienryhmän teemaan liittyen. Työpajan vetäjä kiinnitti ideat sermeille kaikkien nähtäväksi. Sen jälkeen vetäjän johdolla käytiin kaikki ideat läpi, ja ne luokiteltiin osallistujien näkemyksen perusteella vastuun eri ulottuvuuksien alle käyttäen jäsennyksenä TBL-kolmijakoa. Ryhmän jäsenillä oli samalla mahdollisuus tarkentaa ideoiden sisältöä. Visuaalisena ratkaisuna kolme vastuun ulottuvuutta esitettiin kolmiona, jolloin ideoita oli mahdollista asettaa kolmion kärkien ohella myös sen sivuille ja keskiöön.

Ryhmittelyn jälkeen jatkettiin arvottamalla ideoita. Jokaisella osallistujalla oli käytössään 3 x 2 plussaa ja 3 x 1 plussaa, yhteensä yhdeksän "ääntä", jotka voitiin jakaa kuudelle eri idealapulle. Plussien avulla otettiin kantaa eri ideoiden tärkeyteen ( 1 plussa = tärkeää, 2 plussaa = erittäin tärkeää). Pienryhmäkeskustelun lopuksi tehtiin A1-kokoiselle paperille yhteenveto ryhmän keskeisistä tuotoksista eniten ääniä saaneiden ideoiden mukaisesti. Kaikkien pienryhmien työskentelyn tuotokset olivat työpajan päätteeksi esillä kaikkien osallistujien tutustuttavina ja kommentoitavina. Tilaisuus päättyi yhteenvetojen lyhyeen esittelyyn ja loppukeskusteluun.

Työpajojen keskustelu ja tuotokset dokumentoitiin nauhoittamalla pienryhmäkeskustelut, valokuvaamalla ryhmien tuotokset (idealaput, ideoiden jäsennys TBL-kolmiolle, ryhmän yhteenvedot) ja tekemällä muistiinpanoja keskusteluista. Heti työpajan jälkeen työpajoissa tuotetuista ideoista ja keskustelun kulusta laadittiin muistiot, jotka on julkaistu hankkeen blogissa (http://ktkblog.kuluttajatutkimus.fi/vastuu/).

\section{Työpajatulokset ja tulosten tarkastelu}

Kolmessa työpajassa tuotettiin yhteensä noin 450 vastuullisuuteen liittyvää idea (ruisleipä n. 170 ideaa, broilerituotteet n. 130 ideaa ja margariini n. 150 ideaa). Monia vastuullisuusideoita oli vaikea luokitella yksittäisten TBL-ulottuvuuksien alle, vaan niiden nähtiin linkittyvän kahteen tai jopa kaikkiin kolmeen ulottuvuuteen. Esimerkiksi margariinityöpajassa kaikista tuotetuista ideoista noin neljännes luokiteltiin TBL-kolmion keskiöön, ts. monet vastuullisuuskysymyksistä nähtiin hyvin kokonaisvaltaisina. Ruisleivän osalta ideoita tuotettiin yhtä paljon sekä tuotteeseen että tuotantoketjuun liittyen. Margariinituotteiden ja myös broilerituotteen osalta suurin osa ideoista liittyi tuotantoketjuun.

Taulukkoon 1 on koottu ne ideat ja asiat, jotka saivat työpajassa osallistujilta eniten pisteitä. Ruisleivän vastuullisuuskeskustelussa löytyi yhteisiä nimittäjiä eri pienryhmien ja -teemojen välillä. Kaikissa ruisleipätyöpajan pienryhmissä nousivat jollakin tavalla esiin ympäristöasiat ja ekologisuus, tuoteturvallisuus ja ympäristön puhtaus sekä toimeentulo ja kannattavuus tuotantoketjussa. Erityisesti huoli kohdistui maatalousyrittäjien taloudellisiin olosuhteisiin. Myös terveellisyyskysymykset liittyen sekä tuotteiden terveellisyyteen että terveellisyydestä huolehtimiseen tulivat esille. Tärkeäksi nousi myös viestintä oikean tiedon ja läpinäkyvyyden näkökulmasta. Eri pienryhmissä saatettiin kuitenkin tulkita asioita eri näkökulmista. Esimerkiksi vaikka työpajan tausta-aineistossa kuvattiin rukiintuotannon vaikutuksia muun muassa ilmastonmuutokseen ja vesistöjen rehevöitymiseen, monet osallistujat liittivät ympäristökysymykset enemmänkin maaperän puhtauteen ja kemikaalien ja lannoitteiden käyttöön. Ruisleipätyöpajassa keskustelu oli broileri- ja margariinityöpajoihin verrattuna arvolatautuneempaa. Tämä ainakin osittain johtui ruisleivän vahvasta sidoksesta kansalliseen identiteettiin. Keskustelu kulminoitui osin rukiin kotimaisuus-kysymykseen, vaikka raaka-aineiden osuus ruisleivän kuluttajahinnasta on vain muutaman prosentin luokkaa.

Broilerituotteiden työpajassa vastuullisuuden kannalta tärkeinä pidetyissä asioissa esiintyi enemmän hajontaa kuin ruisleipätyöpajassa. Yhtään ideaa ei jaettu kaikkien pienryhmien kesken. Huoli ympäristöstä nousi kuitenkin esiin kahdessa pienryhmässä, ja kuten ruisleipätyöpajassa myös tässä tapauksessa ympäristöasiat nousivat ketjun kokonaisvastuullisuuden näkökulmasta tärkeimmäksi teemaksi. Kiinnostavana ympäristödialogin piirteenä oli, että ketjun toimijat ja asiantuntijat puhuivat ympäristöasioista taloudellisin termein (esim. ekotehokkuus, tuotantopanosten tehokas käyttö), kun taas kuluttajat käyttivät enemmän yleisiä ympäristötermejä kuten vesistöjen saastuminen. Muita keskeisiä vastuullisuuden teemoja olivat eläinten hyvinvointi, puhtaus ja tuoteturvallisuus sekä kuluttajien rooli ja vastuu mukaan lukien kuluttajille suunnattu informaatio. Lintujen hyvinvointiin liittyvät kysymykset olivat keskeisiä mutta eivät kuitenkaan keskustelua hallitsevia, kun puhuttiin koko broilerituotteiden arvoketjun vastuullisuudesta. 
Taulukko 1. Työpajojen pienryhmien eniten ääniä saaneet vastuullisuusideat (äänimäärät suluissa). Pienryhmissä oli 9-11 osallistujaa. Maksimipistemäärä idealle oli 18-22 pistettä, 2 pistettä per osallistuja. Maksimipistemäärä ideaa kohden on suluissa pienryhmän otsikon jälkeen. Suuri pistemäärä kertoo laajasta idean kannatuksesta.

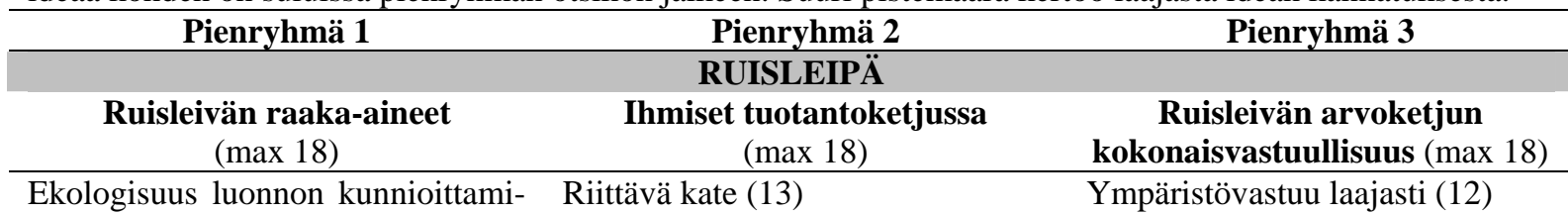

sena, kestävänä viljelynä ja maan tuottokykynä (18)

Puhtaus ja terveellisyys (14) Kuluttajille turvalliset tuotteet (10)

Oikeudenmukainen hinnanmuodostus (9)

Kansallinen identiteetti ml. kulttuu- Ympäristöstä huolehtiminen (9) rinen näkökulma (12)

Viljelyn jatkuvuus (9)

Työhyvinvointi*

Terveellisyys/terveelliset tuotteet

(9)

Toimeentulo ja palkkaus*

Oikeaa tietoa tuotteesta (8)

BROILERITUOTTEET

Broilerituotannon ympäristövaikutukset (max 20)

\section{Eläinten terveys ja tuoteturvallisuus} $(\max 22)$

Eläinten hoito (15)

Turvalliset tuotteet (7)

\section{Broilerituotteiden arvoketjun kokonaisvastuullisuus (max 20)}

Koko ketjun prosessien tehokkuus ja tuotantopanosten tehokas käyttö (11)

Tulevaisuudesta huolehtiminen (10)

Eläinten hyvät elinolot (13)

Kotimainen energia ja ruoka läheltä Avoin tiedottaminen (13)

(10)

Kuluttajien toimet (10)

Tuottajien hyvinvointi (10)

Eläinten hyvinvoinnista huolehti- Puhtaus koko tuotantoketjussa (10) minen (9)

Käytetään parasta tekniikkaa ja Elintarvikevalvonta (9) osaamista (8)

Ympäristön vähäinen kuormitus (8) Vastuullinen kuluttajuus (8)

\begin{tabular}{|c|c|c|}
\hline \multicolumn{3}{|c|}{ MARGARIINI } \\
\hline $\begin{array}{l}\text { Margariinien raaka-aineet } \\
\text { (max 20) }\end{array}$ & $\begin{array}{l}\text { Margariinien valmistus } \\
\qquad(\max 22)\end{array}$ & $\begin{array}{c}\text { Margariinien arvoketjun koko- } \\
\text { naisvastuullisuus } \\
(\max 20)\end{array}$ \\
\hline Ympäristövaikutukset (9) & Turvallinen tuote kuluttajalle (13) & Tyytyväinen kuluttaja (12) \\
\hline $\begin{array}{l}\text { Sosiaalisesti oikeudenmukainen } \\
\text { tuotanto (9) }\end{array}$ & $\begin{array}{l}\text { Ympäristön ongelmat huomioon } \\
\text { (10) }\end{array}$ & Pitkäjänteisyys (11) \\
\hline Terveysvaikutukset (8) & Henkilöstön hyvinvointi (9) & Yhteistyö ketjun osien välillä (9) \\
\hline $\begin{array}{l}\text { Taloudellisuus yritykselle, osak- } \\
\text { keenomistajille ja tuottajille (7) }\end{array}$ & $\begin{array}{l}\text { Kattavat tuoteselosteet pakkauk- } \\
\text { sissa (7) }\end{array}$ & $\begin{array}{l}\text { Työntekijöiden asema eri maissa } \\
\text { (8) }\end{array}$ \\
\hline $\begin{array}{l}\text { Oikeudenmukainen tulonjako ket- } \\
\text { jussa (7) }\end{array}$ & $\begin{array}{l}\text { Energian säästö tuotannossa ja } \\
\text { kulutuksessa (7) }\end{array}$ & $\begin{array}{l}\text { Kokonaisuuden ymmärtäminen } \\
\text { (7) }\end{array}$ \\
\hline Jäljitettävyys (7) & $\begin{array}{l}\text { Luo hyvinvointia - työpaikat (7) } \\
\text { Kilpailukykyinen laatu (7) }\end{array}$ & \\
\hline
\end{tabular}

* Pienryhmän osallistujat nostivat nämä asiat yhteenvetoon, koska niihin liittyen tuotettiin useita ideoita.

Margariinityöpajassa yhteisiä nimittäjiä eri pienryhmien välillä oli vähiten. Ympäristökysymykset olivat esillä varsin yleisellä tasolla. Kuluttajanäkökulma oli suhteellisen vahva ollen tärkeimpänä asiana yhteenvedossa kahdessa pienryhmässä. Myös jäljitettävyyden merkitys korostui. Margariinityöpajan dialogissa tuli esiin tapausesimerkin moniulotteisuus, ja eri pienryhmien välillä äänet tärkeäksi koettujen vastuullisuusasioiden kannalta fragmentoituivat enemmän kahteen muuhun työpajaan verrattuna. Rypsillä margariinin raaka-aineena ei myöskään ollut samanlaista arvolatausta kuin rukiilla ruisleipätyöpajassa. Globaalit kysymykset puolestaan nousivat keskusteluun muita työpajoja enemmän, ja osin ehkä tästä syystä monet vastuukysymykset nähtiin hyvin kokonaisvaltaisina sisältäen sekä taloudellisen ja sosiaalisen vastuun että ympäristövastuun näkökulmia. 


\section{Johtopäätökset}

Tulosten perusteella ympäristöasiat ovat vastuullisuuden kannalta keskeisessä roolissa. Huoli ympäristöstä on yhteinen kaikkien esimerkkiketjujen osalta. Vastuullisuuteen liitettiin vahvasti myös oikeudenmukainen tulonjako ketjussa, terveellisyys, puhtaus ja tuoteturvallisuus, kuluttajan vastuu sekä broileriketjun kohdalla eläinten hyvinvointi. Työpajojen tuotoksia tulkittaessa on otettava huomioon, että ne perustuvat työpajoihin rekrytoitujen ihmisten näkemyksiin ja osallistujien vuorovaikutukseen.

Monet työpajoissa tuotetuista ideoista pysyivät hyvin yleisellä tasolla, eikä dialogissa päästy niin konkreettiselle tasolle, kuin etukäteen toivottiin. Vastuullisuus osoittautui aiheena vaikeasti haltuun otettavaksi. Vastuullisuuden kriteerien ja mittareiden kehittäminen edellyttää sidosryhmädialogin jatkamista ja hieman ohjatumpaa työpajatyöskentelyä.

Elinkaarilähtöinen ajattelutapa vastuullisuuden arviointiin sai kannatusta sidosryhmäkeskusteluissa. Hankkeen ketjulähtöinen vastuullisuuden tarkastelu edellyttäisi elinkaariajattelun laajentamista myös sosiaalisen vastuun kysymyksiin. Laajennetun LCA-metodologia soveltamista sosiaalisen vastuun tarkasteluun on tuotu esiin myös alan kirjallisuudessa (esim. Gauthier 2005).

Hanke vahvistaa sidosryhmädialogin tarvetta vastuullisuuden sisällön rakentamiseksi, vaikka konsensuksen saavuttaminen vastuullisuuden jaetun käsityksen rakentamiseksi onkin haasteellinen ja pitkä prosessi. Tulokset auttavat elintarvikealalla toimivia yrityksiä hahmottamaan, millä vastuullisuuden osa-alueella olisi eniten merkitystä kuluttajille ja muille sidosryhmille. Hanke tarjoaa myös aineksia vastuullisuudesta käytävään yhteiskunnalliseen ja poliittiseen keskusteluun.

Tutkimusprosessi on osoittautunut ainutlaatuiseksi oppimisprosessiksi niin tutkijoille kuin yritysten edustajillekin ja sidosryhmien edustajille. Yritysten edustajat ovat kokeneet sidosryhmätyöpajoissa käydyn keskustelun hyödyllisenä oman liiketoimintansa kannalta. Joissakin yrityksissä on yritysten edustajien mukaan jo nyt hyödynnetty hankkeen aikana tuotettua tietoa yritysten yhteiskuntavastuuraporteissa sekä toiminnan kehittämisessä. Tutkimushanke jatkuu vastuullisuuden kriteerien ja mittareiden kehittämisellä.

\section{Lähteet}

Elkington, J. 1997. Cannibals with Forks. The Triple Bottom Line of $21^{\text {st }}$ Century Business. Oxford: Capstone Publishing Ltd.

Cramer, J., van der Heijden, A. \& Jonker, J. 2004. Corporate Social Responsibility: Balancing Between Thinking and Acting. No. 28-2004 ICCSR Research Paper Series. International centre for corporate social responsibility, The University of Nottingham.

Forsman-Hugg, S., Mäkelä, J., Paananen, J., Pesonen, I., Isoniemi, M. \& Kurppa, S. 2006. Laatu- ja vastuukysymyksiä elintarvikeketjussa. Maa- ja elintarviketalous 83. Helsinki: MTT. 123 s.

Gauthier, C. 2005. Measuring Corporate Social and Environmental Performance: The Extended Life-Cycle Assessment. Journal of Business Ethics. 59: 199-206.

Glaser, B. G. \& Strauss, A. L. 1967. The discovery of grounded theory: strategies for qualitative research. New York: Aldine de Gruyter.

Heiskanen, E. 2005. Taming the Golem - an experiment in participatory and constructive technology assessment. Science Studies 18 (1): 52-74.

Katajajuuri, J-M., Tuhkanen, H-R., Voutilainen, P. 2005. Contribution of life cycle stages to the global warming potential of food products. In: Innovation by life cycle management, LCM 2005 Iinternational Conference: Proceedings, September 5-7, 2005, Barcelona, Spain. p. 414-418.

Korhonen, J. 2003a. Should we measure corporate social responsibility? Corporate Social Responsibility and Environmental Management, 10: 25-39.

Korhonen, J. 2003b. On the ethics of corporate social responsibility - considering the paradigm of industrial metabolism. Journal of Business Ethics, 48: 301-315.

Salzmann, O., Ionescu-Somers, A. \& Steger, U. 2005. The Business Case for Corporate Sustainability: Literature Review and Research Options. European Management Journal, 23 (1): 27-36.

Veleva, V. \& Ellenbecker, M. 2000. A Proposal for Measuring Business Sustainability: Addressing Shortcomings in Existing Frameworks. GMI, 31: 101-120.

Wilenius, M. 2005. Towards the age of corporate responsibility? Emerging challenges for the business world. Futures. 37:133-150. 